\title{
THE INFLUENCE OF BODILY HYDRATION ON THE RENAL CONCENTRATING PROCESS ${ }^{1}$
}

\author{
By FRANKLIN H. EPSTEIN,2 CHARLES R. KLEEMAN, AND \\ ACHIEL HENDRIKX \\ (From the Department of Internal Medicine, Yale University School of Medicine, \\ New Haven, Conn.)
}

(Submitted for publication December 7, 1956; accepted December 28, 1956)

Although the ability of the kidneys to produce a concentrated urine is widely used in the clinic as a measure of renal function, there have been few systematic studies of factors affecting maximum urinary concentration in normal persons. It is clear that a major influence on renal reabsorption of water is exerted by the antidiuretic hormone of the posterior pituitary $(\mathrm{ADH})$; however, Shannon pointed out that, even in the absence of exogenous or endogenous Pitressin ${ }^{\otimes}$, dogs with diabetes insipidus could elaborate a concentrated urine when they were severely dehydrated (1). It has been observed repeatedly that injecting large amounts of posterior pituitary substance into hydrated normal subjects does not produce as concentrated a urine as does prolonged dehydration (2-6).

The present experiments were designed to explore some of the effects of bodily hydration in altering the response of normal kidneys to maximum doses of $\mathrm{ADH}$. The results indicate that chronic underhydration as well as prolonged forcing of fluids drastically modify the ability of the kidneys to reabsorb water and to concentrate solutes in the urine.

\section{METHODS}

Normal young men subsisted for three days on a) a Dehydration diet containing no water or liquid food, b) an $A d$ lib regimen in which the same food was taken, but no restriction was placed on drinking, or c) an Overhydration regimen, which differed from the preceding only in that 5 to 6 liters of water were imbibed in divided doses throughout the day. Each individual served as his own control by participating in at least two experiments

1 Supported by grants from the U. S. Public Health Service, the Wyndham County, New Haven (Conn.) and American Heart Associations and a contract (MD-116) with the Office of the Surgeon General, Department of the Army.

2 Established Investigator of the American Heart Association. of different types. In some subjects the sequence was repeated in exactly the same way, but the protein content of the diet was varied. Results of varying the intake of protein will be discussed in detail separately (7). On the morning of the fourth day the subject reported to the laboratory, having abstained from food and fluids for the preceding 12 hours. In order to assure a constant and maximal antidiuretic stimulus, Pitressin 8 was infused throughout all experiments at the rate of 200 milliunits per hour in $50 \mathrm{cc}$. of 0.9 per cent saline containing inulin. This dose of Pitressin is approximately four times the amount needed to produce a maximally concentrated urine in normal human subjects (8). Subjects remained in the supine position, standing only to void every half-hour or hour. After two to three hours, when urinary osmolality had reached a plateau, 10 per cent mannitol was infused intravenously at $20 \mathrm{cc}$. per min. into some subjects without interrupting the administration of Pitressin. After the flow of urine had reached $15 \mathrm{cc}$. per min. urine was collected every ten minutes for 5 to 11 separate determinations of $\mathrm{T}_{\mathrm{m}}{ }^{c} \mathrm{H}_{2} \mathrm{O}$ (9) within a range of urine flows between 15 to $30 \mathrm{cc}$. per min. In any one experiment, throughout the range of urine flows studied, individual determinations of $\mathrm{T}_{\mathrm{m}}{ }^{\mathrm{e}} \mathrm{H}_{2} \mathrm{O}$ did not vary more than $0.5 \mathrm{cc}$. per min. from the mean. Venous blood was collected from the arm at appropriate intervals through an indwelling needle. Osmolality of serum and urine was determined with a Fiske osmometer. The quantity of solute-free water $\left(\mathrm{T}_{\mathrm{m}}{ }^{\mathrm{c}} \mathrm{H}_{2} \mathrm{O}\right)$ required to restore the urine to an isosmotic state with respect to the glomerular filtrate was calculated as the difference between osmolar clearance and urine flow. Serum sodium was measured with a flame photometer. Clearances of urea (10) and inulin (11) were also measured. Data were analyzed with "Student's" " $t$ " test.

\section{RESULTS}

\section{General}

Throughout the three days of dehydration subjects experienced moderate thirst, particularly marked after eating. Salivary flow, however, was not grossly diminished and although the tongue and mouth felt dry, they did not look dry. An increase in fatigue and irritability and loss of mental

\footnotetext{
${ }^{3}$ Parke, Davis and Co. Lot Number R983M.
} 


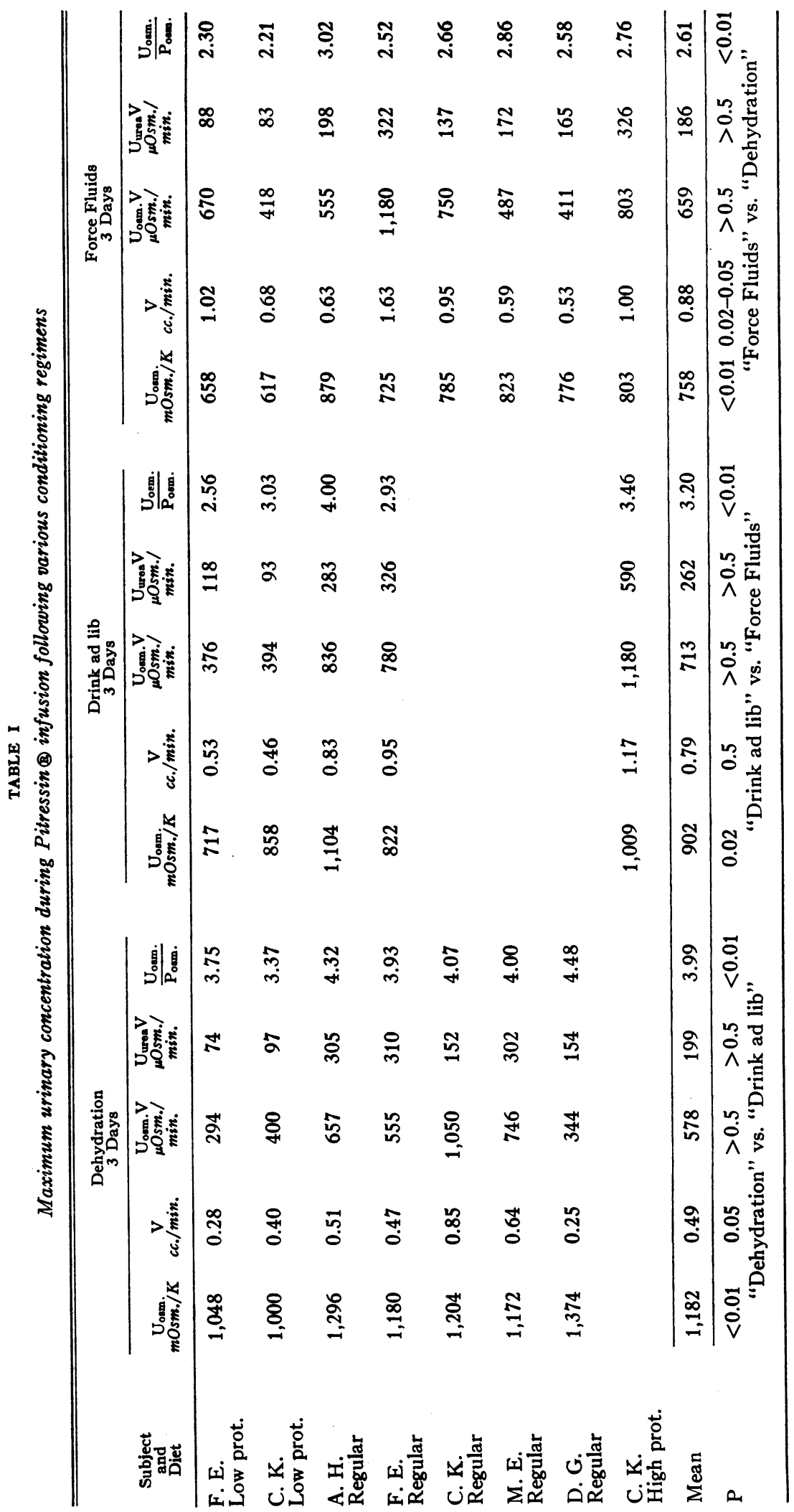




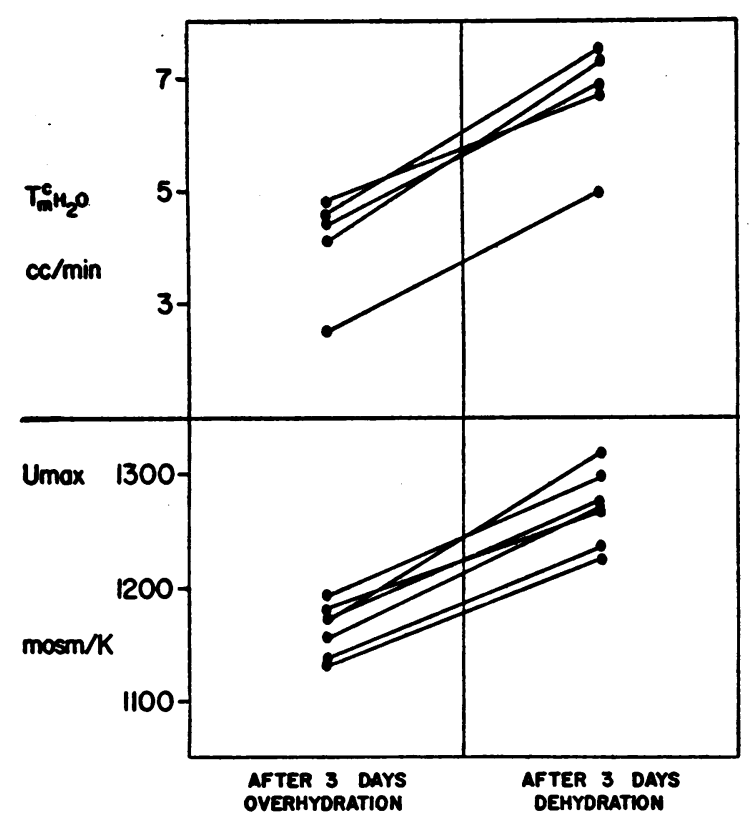

Fig. 1. EFfect of Bodily Hydration on Renal Concentrating Ability

efficiency were uniformly reported. Daily output of urine varied from 350 to $700 \mathrm{cc}$. Thirst as well as fatigue were somewhat ameliorated in two subjects by $5 \mathrm{mg}$. of d-amphetamine sulfate twice a day, as suggested by Adolph (12). In contrast, while drinking 5 to 6 liters of water per day for three days, subjects reported less fatigue and no malaise, but usually developed an understandable aversion to water. One subject reported a perceptible increase in nervousness. The phenomenon of continued thirst after cessation of forced drinking (13) was not encountered.

During the infusion of hypertonic mannitol subjects frequently experienced headache when they stood up to void, which was completely relieved by straining in the Valsalva maneuver or by lying down, a sequence suggestive of lowered cerebrospinal fluid pressure.

\section{Maximum urinary concentration at low flows (Table I, Figure 1)}

The solute concentration of the urine and the ratio of osmolality of urine to that of plasma achieved after maximal stimulation with Pitres$\sin$ were consistently greater in all subjects following a dehydrating regimen than after a preliminary period of forcing fluids. Moreover, dehydration raised and overhydration lowered the maximum concentration of the urine and maximum $U / P$ ratio when compared with values achieved by the same subject after three days of drinking fluids "ad lib." During the three days of water restriction the osmolality of urine collected on successive days before breakfast rose progressively and was not increased further by Pitressin. The output of total solutes and the excretion of urea, measured on the experimental

TABLE II

Effect on $T_{m}{ }^{c} \mathrm{H}_{2} \mathrm{O}, \mathrm{C}_{\mathrm{ln}}$ and $\mathrm{C}_{\text {urea }}$ of forced drinking $(F D)$ and dehydration $(D)$ *

\begin{tabular}{|c|c|c|c|c|c|c|c|c|c|c|}
\hline $\begin{array}{l}\text { Subject and } \\
\text { Surface area }\end{array}$ & Regimen & $\begin{array}{l}\mathrm{T}_{\mathrm{m}} \cdot \mathrm{H}_{2} \mathrm{O} \\
c c . / \min .\end{array}$ & $\underset{c c . / m i n .}{C_{I_{n}}}$ & $\frac{\mathrm{T}_{m} \cdot \mathrm{H}_{2} \mathrm{O}}{\mathrm{C}_{\mathrm{In}}} \times 100$ & $\underset{c c . / m i n}{C_{\text {mon }}}$ & $\frac{C_{\text {uroen }}}{C_{\text {In }}}$ & $\begin{array}{c}\text { Extremes of } \\
\text { urine flow } \\
c c . / \min \text {. }\end{array}$ & $\underset{\mathrm{Na}}{\substack{\text { Serum } \\
m E q . / L .}}$ & $\begin{array}{l}\text { Serum } \\
\text { osm. } \\
m O \mathrm{sm} . / K\end{array}$ & 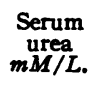 \\
\hline $\begin{array}{l}\text { F. E. } \\
1.8\left(\mathrm{~m} .{ }^{2}\right)\end{array}$ & $\begin{array}{l}\text { FD } \\
\text { D }\end{array}$ & $\begin{array}{l}4.8 \\
6.7\end{array}$ & $\begin{array}{l}103 \\
107\end{array}$ & $\begin{array}{l}4.7 \\
6.3\end{array}$ & $\begin{array}{l}80 \\
82\end{array}$ & $\begin{array}{l}78 \\
77\end{array}$ & $\begin{array}{l}20-30 \\
20-30\end{array}$ & $\begin{array}{l}141 \\
148\end{array}$ & $\begin{array}{l}288 \\
300\end{array}$ & $\begin{array}{r}7.3 \\
11.8\end{array}$ \\
\hline $\begin{array}{l}\text { R. S. } \\
1.9\left(\mathrm{~m} .{ }^{2}\right)\end{array}$ & $\begin{array}{l}\text { FD } \\
\text { D }\end{array}$ & $\begin{array}{l}4.4 \\
6.9\end{array}$ & $\begin{array}{l}108 \\
100\end{array}$ & $\begin{array}{l}4.1 \\
6.9\end{array}$ & $\begin{array}{l}86 \\
79\end{array}$ & $\begin{array}{l}79 \\
80\end{array}$ & $\begin{array}{l}22-35 \\
17-23\end{array}$ & $\begin{array}{l}155 \\
150\end{array}$ & $\begin{array}{l}300 \\
296\end{array}$ & $\begin{array}{l}8.6 \\
6.7\end{array}$ \\
\hline $\begin{array}{l}\text { M. E. } \\
1.9\left(\mathrm{~m} .{ }^{2}\right)\end{array}$ & $\begin{array}{l}\text { FD } \\
\text { D }\end{array}$ & $\begin{array}{l}4.6 \\
7.5\end{array}$ & $\begin{array}{l}98 \\
95\end{array}$ & $\begin{array}{l}4.7 \\
7.9\end{array}$ & $\begin{array}{l}73 \\
79\end{array}$ & $\begin{array}{l}75 \\
83\end{array}$ & $\begin{array}{l}18-29 \\
18-25\end{array}$ & $\begin{array}{l}151 \\
153\end{array}$ & $\begin{array}{l}287 \\
294\end{array}$ & $\begin{array}{l}4.4 \\
8.1\end{array}$ \\
\hline $\begin{array}{l}\text { D. G. } \\
2.1\left(\mathrm{~m} .{ }^{2}\right)\end{array}$ & $\begin{array}{l}\text { FD } \\
D\end{array}$ & $\begin{array}{l}4.1 \\
7.3\end{array}$ & $\begin{array}{l}150 \\
135\end{array}$ & $\begin{array}{l}2.7 \\
5.4\end{array}$ & $\begin{array}{l}90 \\
92\end{array}$ & $\begin{array}{l}60 \\
68\end{array}$ & $\begin{array}{l}22-30 \\
20-27\end{array}$ & $\begin{array}{l}146 \\
148\end{array}$ & $\begin{array}{l}291 \\
293\end{array}$ & $\begin{array}{l}6.0 \\
8.4\end{array}$ \\
\hline $\begin{array}{l}\text { A. H. } \\
1.7\left(\mathrm{~m} .{ }^{2}\right)\end{array}$ & $\begin{array}{l}\text { FD } \\
D\end{array}$ & $\begin{array}{l}2.5 \\
5.0\end{array}$ & $\begin{array}{l}93 \\
86\end{array}$ & $\begin{array}{l}2.7 \\
5.8\end{array}$ & $\begin{array}{l}75 \\
69\end{array}$ & $\begin{array}{l}81 \\
80\end{array}$ & $\begin{array}{l}15-33 \\
20-30\end{array}$ & $\begin{array}{l}139 \\
156\end{array}$ & $\begin{array}{l}301 \\
307\end{array}$ & $\begin{array}{l}5.2 \\
8.4\end{array}$ \\
\hline Mean & $\begin{array}{l}\text { FD } \\
\text { D }\end{array}$ & $\begin{array}{l}4.08 \\
6.68\end{array}$ & $\begin{array}{l}110 \\
104\end{array}$ & $\begin{array}{l}3.78 \\
6.46\end{array}$ & $\begin{array}{l}81 \\
80\end{array}$ & $\begin{array}{l}75 \\
78\end{array}$ & & $\begin{array}{l}147 \\
151\end{array}$ & $\begin{array}{l}293 \\
298\end{array}$ & $\begin{array}{l}6.3 \\
8.7\end{array}$ \\
\hline $\mathbf{P}$ & & $<0.01$ & $0.1-0.2$ & $<0.01$ & $>0.5$ & $>0.5$ & & $0.2-0.3$ & $0.2-0.3$ & $<0.01$ \\
\hline
\end{tabular}

* All clearances were measured during mannitol diuresis, within the urine flows indicated. 
morning during infusion of Pitressin', were not altered consistently by preliminary water deprivation or water drinking.

\section{$T_{m}{ }^{\circ} H_{2} \mathrm{O}, \mathrm{C}_{\mathrm{In}}, \mathrm{C}_{\text {urea }}$ (Table II, Figure 1)}

The maximum quantity of "free" water reabsorbed per minute by the kidneys during mannitol diuresis $\left(\mathrm{T}_{\mathrm{m}}{ }^{\circ} \mathrm{H}_{2} \mathrm{O}\right)(9)$ was strikingly altered in every subject by preliminary regimens of dehydration or overhydration. Mean $\mathrm{T}_{\mathrm{m}}{ }^{\mathrm{c}} \mathrm{H}_{2} \mathrm{O}$ following dehydration in five subjects was $6.7 \mathrm{cc}$. per min., averaging 65 per cent more than in the same man following a period of three days during which fluids had been forced. The effect of fluid deprivation was not eliminated by permitting one subject, F. E., to slake his thirst after the infusion of Pitressin ${ }^{8}$ had been started but before mannitol was injected.

Inulin clearances measured during an infusion of 10 per cent mannitol were usually slightly lower in subjects who had been dehydrated than they were after a period of overhydration; no difference, however, was greater than 10 per cent. Although the concentration of urea in the serum was usually higher after a subject was dehydrated than after overhydration, there was no consistent difference in urea clearance measured during the infusion of hypertonic mannitol nor any significant alteration at these high flows in the ratio of urea clearance to inulin clearance (average, 0.75 ).

\section{Effect of chronic administration of Pitressin ${ }^{\circledR}$} (Figure 2)

A possible mechanism for the augmenting effect of prolonged dehydration on the concentrating

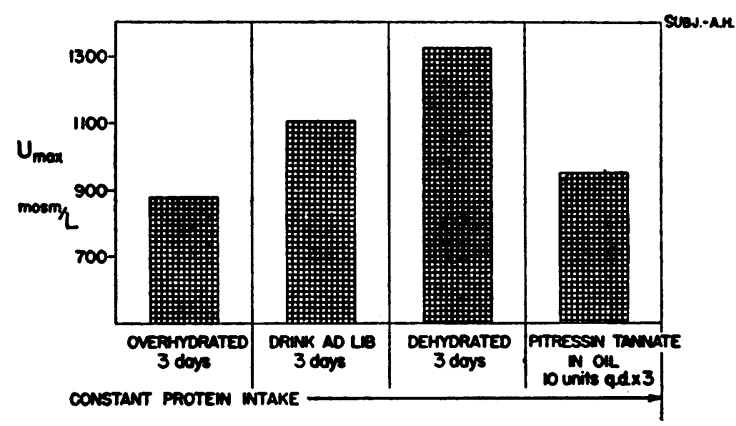

Fig. 2. Effect of Bodily Hydration and Chronic Administration of Pitressine on Maxmude Urinary Concentration process might involve the adaptation of renal tubules to high circulating levels of antidiuretic hormone liberated by the posterior pituitary in the dehydrated state. This possibility was put to the test on four occasions in three subjects in whom 5 units of Pitressin Tannate in Oil were injected intramuscularly twice a day for three days while they were permitted to drink water ad lib. In this way a high level of antidiuretic hormone was maintained in body fluids and the kidneys were induced to concentrate maximally despite a normal or slightly expanded volume of body water. Under these circumstances, maximum urinary concentration, tested on the fourth day, did not rise above that achieved after a preparatory period of drinking at will and did not reach the heights attained after preliminary dehydration. Figure 2 is representative of these experiments.

\section{DISCUSSION}

It seems clear that the ability of normal kidneys to concentrate the urine in response to Pitressin may be significantly altered by a preparatory period of dehydration or of forced drinking. This effect on concentrating capacity was apparent not only at low urine flows, on maximum urinary concentration and $U / P$ ratio, as reported by Jones and de Wardener (6) and West, Traeger, and Kaplan (4), but also on the maximum tubular reabsorptive capacity for "free" water, measured during osmotic diuresis. The magnitude of this adaptation suggests that it is of considerable physiological importance. Under conditions of prolonged dehydration, from 25 per cent to 50 per cent of urinary water losses could be conserved for bodily needs through its operation.

Several possible causes for this phenomenon are excluded or indicated by the present study. It is unlikely that differences in the amounts of circulating endogenous antidiuretic substance on the experimental day could have influenced the results, since the dose of exogenous Pitressin injected was always well above that required to produce a maximally concentrated urine. Berliner and Davidson (14) have reported that large reductions in glomerular filtration rate produced by unilateral compression of the renal artery in dogs result in more complete reabsorption of water by the kidney whose blood supply is restricted. In 
the present experiments, alterations in glomerular filtration rate in the same subject on different regimens were inconstant and minor. Although changes in the excretion of total solutes $(15,16)$ and of urea (7) may modify the osmotic ceiling of the urine during administration of Pitressin these factors were not consistently altered by water deprivation or forced drinking in the present experiments.

McCance and Young (17) and Miles, Paton, and de Wardener (5) observed that the maximum concentration of solutes in the urine increased progressively with prolonged water deprivation. West, Traeger, and Kaplan (4) and Jones and de Wardener (6) noted further that the effect of prior fluid deprivation in enhancing renal concentrating ability was not acutely reversed by rehydrating subjects after Pitressin had been injected. Both observations, confirmed in the course of the present study, suggest that the adaptive response of the renal tubules to changes in bodily hydration is a cumulative rather than an instantaneous one, with a certain lag recalling the adaptive behavior of the kidneys with respect to the excretion of ammonia, when acid is given over several days.

The improved response of the kidneys after several days of water restriction is apparently an adjustment to something other than prolonged exposure to antidiuretic hormone. Concentrating ability was not augmented when the kidneys were forced to excrete a concentrated urine continuously for three days by injections of Pitressin Tannate in Oil. It would appear that the renal concentrating process is conditioned by the state of hydration of body tissues (including, and perhaps most important, the cells of the distal and collecting tubules themselves). Evidence is lacking at the present time to say whether this influence is exerted at the site of action of Pitressin ${ }^{8}$ or upon a separate concentrating mechanism (9).

One might predict from the results of these studies that severe reversible functional impairment of water reabsorption, resembling diabetes insipidus, would result from prolonged overdrinking. This may be the explanation of Kunstmann's report (13) of continuing thirst following a period of 8 to 12 days of over-drinking. One of us (C. K.) has recently observed a patient with psychogenic polydipsia of 15 years' duration, unable to concentrate the urine to more than $300 \mathrm{mOsm}$. per $K$, who gradually regained the ability to concentrate normally in response to Pitressin after several weeks during which a normal intake of fluid was imposed.

\section{SUMMARY}

1. The contrasting effects of water deprivation and forced drinking upon renal concentrating ability were studied in normal subjects.

2. Preliminary water deprivation increased and forced drinking decreased the maximum urinary concentration achieved after Pitressin $\otimes$.

3. $\mathrm{T}_{\mathrm{m}}{ }^{\mathrm{C}} \mathrm{H}_{2} \mathrm{O}$ was 40 to 100 per cent higher in the same subject after dehydration than after overhydration.

4. Changes in glomerular filtration rate, total solute excretion and the excretion of urea were small and/or inconsistent.

5. Chronic administration of Pitressin Tannate in Oil did not increase maximum urinary concentration.

6. It is suggested that the renal concentrating process is conditioned to an important degree by the state of hydration of body tissues, including those of the kidneys.

\section{REFERENCES}

1. Shannon, J. A., The control of the renal excretion of water. I. The effect of variations in the state of hydration on water excretion in dogs with diabetes insipidus. J. Exper. Med., 1942, 76, 371.

2. Sodeman, W. A., and Engelhardt, H. T., Renal concentration test employing use of pituitary extracts. Response of normal subjects. Proc. Soc. Exper. Biol. \& Med., 1941, 46, 688.

3. Taylor, R. D., Peirce, J. D., and Page, I. H., Use of posterior pituitary extract in tests of urinary concentration. Am. J. M. Sc., 1945, 209, 235.

4. West, C. D., Traeger, J., and Kaplan, S. A., A comparison of the relative effectiveness of hydropenia and of Pitressinis in producing a concentrated urine. J. Clin. Invest., 1955, 34, 887.

5. Miles, B. E., Paton, A., and de Wardener, H. E., Maximum urine concentration. Brit. M. J., 1954, 2, 901.

6. Jones, R. V. H., and de Wardener, H. E., Urine concentration after fluid deprivation or Pitressin Tannate in Oil. Brit. M. J., 1956, 1, 271.

7. Epstein, F. H., Kleeman, C. R., Pursel, S., and Hendrikx, A., The effect of feeding protein and urea on the renal concentrating process. J. Clin. Invest., $1957,36,635$.

8. Lauson, H. D., The problem of estimating the rate 
of secretion of antidiuretic hormone in man. Am. J. Med, 1951, 11, 135.

9. Zak, G. A., Brun, C., and Smith, H. W., The mechanism of formation of osmotically concentrated urine during the antidiuretic state. J. Clin. Invest., 1954, 33, 1064.

10. Conway, E. J., Microdiffusion Analysis and Volumetric Error. 3rd rev. ed., London, C. Lockwood, 1950.

11. Roe, J. H., Epstein, J. H., and Goldstein, N. P., A photometric method for the determination of inulin in plasma and urine. J. Biol. Chem., 1949, 178, 839.

12. Adolph, E. F., Physiology of Man in the Desert. New York, Interscience Publishers, Inc., 1947.
13. Kunstmann, D., Uber die Wirkung der Zufuhr grosser Wassermengen auf den Organismus. Arch. f. exper. Path. u. Pharmakol., 1933, 170, 701.

14. Berliner, R. W., and Davidson, D. G., Production of hypertonic urine in the absence of pituitary antidiuretic hormone. J. Clin. Invest., 1956, 35, 690.

15. Rapoport, S., Brodsky, W. A., West, C. D., and Mackler, B., Urinary flow and excretion of solutes during osmotic diuresis in hydropenic man. Am. J. Physiol., 1949, 156, 433.

16. Smith, H. W., Renal excretion of sodium and water. Federation Proc., 1952, 11, 701.

17. McCance, R. A., and Young, W. F., The secretion of urine during dehydration and rehydration. $\mathrm{J}$. Physiol., 1944, 102, 415.

\section{SPECIAL NOTICE TO SUBSCRIBERS}

Post Offices will no longer forward the Journal when you move.

Please notify The Journal of Clinical Investigation, Business Office, 622 West 168th Street, New York 32, N. Y. at once when you have a change of address, and do not omit the zone number if there is one. 